\title{
ЩОДО ПРОБЛЕМНИХ ПИТАНЬ ЗАСТОСУВАННЯ ЗАПОБІЖНИХ ЗАХОДІВ ЩОДО НЕПОВНОЛІТНІХ
}

Федоров I. B.

у науковій статmі досліджено проблемні питання обрання прокурорами видів запобіжних заходів, передбачених кримінальним процесуальним законодавством, щодо неповнолітніх які вчинили кримінальне правопорушення до слідчих суддів, із відповідними клопотаннями.

Також проведено аналіз причин, за яких запобіжний захід у вигляді тримання під вартою міститься майже у $40 \%$ клопотань прокурорів.

Надані пропозиції щодо внесення відповідних змін до чинного кримінального процесуального законодавства з метою зменшення питомої ваги виду запобіжного заходу у вигляді тримання під вартою щодо неповнолітніх підозрюваних та обвинувачених.

Ключові слова: досудове розслідування, запобіжні заходи, тримання під вартою, особиста порука.

В научной статье исследованы проблемные вопросы избрания прокурорами видов мер пресечения предусмотренных уголовным процессуальным законодательством в отношении несовершеннолетних, которые совершили уголовное правонарушение при обращении к следственным судьям с соответствующими ходатайствами.

Также проведен анализ причин, при которых мера пресечения в виде содержания под стражей содержится почти в 40\% ходатайств прокуроров. Представлены предложения о внесении изменений в действующее уголовное процессуального законодательства с целью уменьшения удельного веса меры пресечения в виде содержания под стражей изби раемых в отношении несовершеннолетних подозреваемых и обвиняемых.

Ключевые слова: досудебное расследование, меры пре сечения, содержание под стражей, личное поручительство.

Fedorov I. V. About the problematic questions of preventive measures regarding juveniles

In this scientific paper are discussed the problematic questions of preparation and election by prosecutors preventive measures which are contained in the Criminal Procedure Code regarding underage suspects or culprits who address to investigating judges with requests. From the moment of signature and further ratification of United Nation Standard Minimal Rules regarding justice of underage ("Beijing rules") by Verkhovna Rada since 29th of November 1985. Ukraine has taken the responsibility of judgment of underage as a part of government's social policy.

Also in the article are analyzed the reasons why the request of detention is contained in almost $40 \%$ of prosecutors' requests to investigating judges.

There are a few of these reasons, including the will of self-prevention of underage's evasion from bodies of pre-trial investigation, reluctance to analyze the surroundings of an underage in order to find an adult, who has enough authority to the suspect or culprit and is able to provide the participation in a process of investigation. Also in the article are shown examples of violation of the legislation in force by the law enforcement officials which leads to the violation of underage individual's rights. Hence during pre-trial investigation are violated the basic principles of international law and national criminal procedure regarding choosing preventive measures for underage suspects or culprits, which has to be the short-term detention in exceptional cases.

For improvements in a present situation and prevention of mass violations of international investigation standards for this category are presented the presented proposals about amendments to the current criminal process legislation with a goal of measure of restraint's reduction in a form of prevention measures regarding underage suspects or culprits.

Author thinks that reduction of the effect of investigating judge's decision in a form of detention for the term of maximum of 30 days, fully meets the requirement of international law about using of such an exceptional preventive measure of deprivation of liberty only for a short term and in exceptional cases.

Key words: pre-trial investigation, preventive measures, detention, personal guarantee.

Постановка проблеми та їі актуальність. Під час проведення досудового розслідування щодо неповнолітніх, які вчинили кримінальні правопорушення, виникають питання щодо обрання запобіжного заходу як виду кримінального процесуального примусу, пов'язаного з рішенням слідчого судді або судом щодо доцільності позбавлення неповнолітньої особи права на свободу та особисту недоторканність.

Вивченням статистичного звіту роботи прокурорів за останні 3 роки встановлено, що майже у 40\% клопотань визначено необхідним застосування запобіжного заходу, пов'язаного з позбавленням волі - тримання під вартою.

Такий стан суперечить вимогам міжнародного та національного законодавства, яке передбачає застосування позбавлення волі щодо неповнолітніх у найменшій кількості випадків.

Аналіз останніх досліджень і публікацій. Кількість злочинів, учинених неповнолітніми донині, залишаючись значною, викликає суспільний резонанс і тому продовжує притягувати увагу з боку науковців.

Вивченню проблеми, пов'язаної з підлітковою злочинністю, а також обґрунтованістю застосування запобіжних заходів, зокрема і щодо неповнолітніх, які вчили кримінальне правопорушення, присвячено роботи Ю.П. Аленіна, П.Д. Біленчука, О.А. Губської, Ю.М. Грошевого, А.Я. Дубинського, Н.С. Карпова, О.М. Ларіна, Л.М. Лобойка, В.З. Лукашевича, М.С. Строговича, В. М. Тертишника, М.Є. Шумила та інших.

Метою статті $\epsilon$ висвітлення причин, унаслідок яких у клопотаннях прокурорів про обрання запобіжного заходу неповнолітнім підозрюваним найчастіше обирається саме найтяжчий - тримання під вартою та визначення змін до чинного кримінального процесуального законодавства, що дозволить збільшити питому вагу застосування інших запобіжних заходів, зокрема такий, як передача під нагляд. 
Виклад основного матеріалу. 3 моменту підписання та подальшої ратифікації Верховною Радою Мінімальних стандартних правил $\mathrm{OOH}$, які стосуються здійснення правосуддя щодо неповнолітніх («Пекінські правила») від 29 листопада 1985 року, Україна взяла на себе обов'язки здійснення правосуддя щодо неповнолітніх за міжнародними положеннями як складник державної соціальної політики.

П. 13 указаних правил визначає таке:

«13.1. Содержание под стражей до суда применяется лишь в качестве крайней меры и в течение кратчайшего периода времени.

13.2. Содержание под стражей до суда по возможности заменяется другими альтернативными мерами, такими, как постоянный надзор, активная воспитательная работа или помещение в семью или в воспитательное заведение или дом» [1].

У 1989 році 44-ю сесією Генеральної Асамблеї ООН у «Конвенції про права дитини», ратифікованому і прийнятому Верховною Радою України 27 лютого 1991 року, зазначено про необхідність гуманного застосування до неповнолітнього запобіжного заходу, пов'язаного з позбавленням волі.

Так, відповідно до положень ст. 37 Конвенції, «<... арешт, затримання чи тюремне ув'язнення дитини здійснюється згідно із законом та використовується лише як конечний захід і протягом якомога більш короткого відповідного періоду часу» [2].

Ст. 9 Конституції України зазначає, що «Чинні міжнародні договори, згода на обов'язковість яких надана Верховною Радою України, $є$ частиною національного законодавства України". [3]

Таким чином, слідчі, прокурори та судді повинні враховувати вимоги міжнародних правових актів, зокрема тих, які стосуються особливостей здійснення правосуддя щодо неповнолітніх, зокрема під час вирішення питання щодо обрання ним виду запобіжного заходу.

Запобіжні заходи це заходи забезпечення кримінального провадження, котрі полягають у тимчасовому обмеженні прав людини згідно із кримінальним процесуальним законодавством, що мають на меті припинити та запобігти новим кримінальним правопорушенням, забезпечити виконання покладених на особу обов'язків та її належну поведінку. [4]

Зважаючи на наведене визначення, метою запобіжних заходів повинно стати саме припинення кримінального правопорушення та запобігання новим.

Щодо неповнолітніх правопорушників це набуває ще додаткового сенсу:

забезпечення подальшого перебування підозрюваного у звичайному йому домашньому оточенні, в якому перебував до моменту вчинення злочину;

неповнолітній підозрюваний не буде перебувати в умовах установи позбавлення волі, у специфічному оточенні, що дозволить не допустити в нього виникнення кримінального «романтизму» та «героїзації» злочинного способу життя.

мінімальний негативний вплив на психіку неповнолітнього.

Ст. 176 Кримінального процесуального Кодексу (далі - КПК) передбачено застосування запобіжних заходів, до яких належать:

1) «особисте зобов'язання;
2) особиста порука;

3) застава;

4) домашній арешт;

5) тримання під вартою.» [5]

Крім того, ст. 493 КПК України передбачає, що до неповнолітніх підозрюваних чи обвинувачених, окрім запобіжних заходів, передбачених ст. 176 КПК, може застосовуватись інший запобіжний захід у вигляді передання їх під нагляд батьків, опікунів чи піклувальників, а до неповнолітніх, які виховуються в дитячій установі, передання їх під нагляд адміністрації цієї установи.

Варто підтримати думку В.О. Січко, що передбачений ст. 493 КПК України спеціальний запобіжний захід передання неповнолітнього підозрюваного чи обвинуваченого під нагляд - $\epsilon$ повноцінним запобіжним заходом і тому має знайти своє законне місце в системі запобіжних заходів, передбачених ст. 176 КПК України, тому що цей спеціальний запобіжний захід розглядається, відповідно до ч. 6 ст. 493 КПК України, за клопотанням прокурора за правилами обрання запобіжного заходу або за клопотанням сторони захисту під час розгляду питання про обрання запобіжного заходу, та згідно з даними узагальнення судової практики Вищого спеціалізованого суду з розгляду цивільних і кримінальних справ від 07.02.2014 року, до неповнолітнього підозрюваного, обвинуваченого, окрім запобіжних заходів, передбачених ст. 176 КПК України, може застосовуватись запобіжний захід у вигляді передання неповнолітнього підозрюваного, обвинуваченого під нагляд батьків, опікунів чи піклувальників, а до неповнолітніх, які виховуються в дитячій установі, - передання їх під нагляд адміністрації цієї установи.

Тобто спеціальний запобіжний захід, що застосовується до неповнолітніх підозрюваних, обвинувачених, містить у своєму змісті всі ознаки запобіжного заходу [6].

На наш погляд, думка В.О. Січко про доповнення переліку запобіжних заходів, які визначені ст. 176 КПК України, наступним - передача під нагляд, $є$ слушною й повністю підтримується.

Водночас аналіз статистичної звітності, зокрема «Про роботу прокурора» (форма №П) за останні три роки свідчать про таке:

Таблиця 1

Подані прокурором клопотання про обрання запобіжних заходів щодо неповнолітніх [7]

\begin{tabular}{|l|l|c|c|c|}
\hline \multicolumn{2}{|c|}{} & $\begin{array}{c}2017 \\
\text { рік }\end{array}$ & $\begin{array}{c}2018 \\
\text { рік }\end{array}$ & $\begin{array}{c}2019 \\
\text { рік }\end{array}$ \\
\hline Подано до суду клопотань (всього) & 987 & 900 & 784 \\
\hline \multirow{3}{*}{ Із них: } & про особисте зобов'язання & 274 & 164 & 153 \\
\cline { 2 - 5 } & про заставу & & & \\
\cline { 2 - 5 } & про домашній арешт & 360 & 398 & 339 \\
\cline { 2 - 5 } & про тримання під вартою & 349 & 333 & 292 \\
\hline
\end{tabular}

Як видно з наведених даних, у 2017 році прокурори 4 рази звертались до суду із клопотанням про обрання запобіжного заходу у вигляді особистої поруки або передачі під нагляд, у 2018 році було подано зазначених 5 клопотань та жодного разу не подавались у 2019 році.

Водночас відсоток клопотань прокурора про обрання запобіжного заходу у вигляді тримання під вартою у 2017 році становив 35\%, у 2018-2019 роках - 37\%.

Крім того, за останні 3 роки слідчими суддями в разі відмови в задоволенні клопотання прокурора в обранні 
запобіжного заходу у вигляді тримання під вартою лише в одному разі (2019 рік) було обрано запобіжний захід у вигляді особистої поруки

Під час проведення досудового розслідування у кримінальних провадженнях щодо неповнолітніх частіше, ніж це необхідно, застосовується запобіжний захід узяття під варту.

На думку Губської О.А., «<..> надмірне бажання застосування запобіжного заходу у вигляді тримання під вартою щодо неповнолітніх, насамперед викликане прагненням слідчих попередити ухилення підлітків від органів досудового розслідування та суду Але навряд чи буде правильним уважати, що цей запобіжний захід - єдиний засіб попередити таке ухилення неповнолітніх»[8]. Зазначена думка $є$ цілком слушною і статистика роботи слідчих підрозділів фактично це підтверджує.

Отримавши клопотання слідчого про застосування запобіжного заходу у вигляді тримання під вартою щодо неповнолітнього підозрюваного, прокурор (процесуальний керівник), а надалі - слідчий суддя, повинні враховувати вік неповнолітньої особи, стан їі здоров'я, рівень загального розвитку, соціальну характеристику, умови життя та виховання, обставини, які негативно впливали на виховання, наявність дорослих співучасників: підмовників та інших осіб, що втягнули неповнолітнього у злочинну діяльність, наявність даних про розумову відсталість підлітка, не пов'язану з душевним захворюванням.

Також необхідно з'ясувати, чи могла ця особа повністю усвідомлювати значення своїх дій, якою мірою могла ними керувати.

Установлення вищевказаних обставин дозволить перевірити виваженість підстав для застосування до неповнолітнього найбільш суворого запобіжного заходу - тримання під вартою та неможливості застосування іншого, більш м'якого, запобіжного заходу.

Необхідно зазначити, що значною помилкою з боку слідчих та прокурорів $€$ вважати запобіжний захід у вигляді тримання під вартою єдиним засобом запобігати ухиленню від слідства з боку неповнолітніх підозрюваних.

Законодавчо визначено те, що неповнолітній підозрюваний може перебувати під наглядом тієї особи, яку вона поважає, котра ії дисциплінує, виховує та стримує, незалежно від того, чи має неповнолітній із нею родинні зв'язки. Звичайно, без згоди особи, що бере на себе такі обов'язки, не обійтись.

Ми вважаємо, що передання неповнолітнього підозрюваного під нагляд $є$ кращим запобіжним заходом за інші, оскільки неповнолітній буде розуміти, що між ним та органом досудового розслідування $\epsilon$ людина, яка несе за нього не лише правову, а й моральну відповідальність.

Також уважаємо, що за правильного визначення особи, якій було передано неповнолітнього правопорушника під нагляд, під час застосування цього запобіжного заходу буде наявний і такий фактор, як почуття сорому з боку підлітка в разі порушення ним слова наданого поручителю.

Водночас інший запобіжний захід, не пов'язаний із позбавленням волі, - це особисте зобов'язання, на нашу думку, не має такої ефективності, у зв'язку з тим, що під час його застосування неповнолітній не бере на себе морального зобов'язання ні перед будь-якою близькою до нього особою.

Переважним фактором під час дотримання вимог цього запобіжного заходу $є$ страх перед покаранням із боку закону, який підліток може подолати за підтримки злочинного оточення.

Але, на жаль, буває так, що батьки, піклувальники, опікуни, адміністрації дитячої установи не викликають довіри в неповнолітнього й тому органам досудового розслідування необхідно з'ясувати, хто саме може позитивно вплинути на дитину, водночас не зважаючи на родинні відносини.

У такій ситуації, окрім вікових особливостей, потрібно досліджувати обставини, котрі стосуються особистості неповнолітнього, а також обставини, які становлять кримінологічну характеристику злочинів, учинених ними.

Визначаючись із запобіжним заходом, який, на думку слідчого, найдоцільніше застосувати до неповнолітнього підозрюваного, необхідно також ураховувати особливості кожного запобіжного заходу, застосовувати індивідуальний підхід до ситуації та ступеня тяжкості кримінального правопорушення.

Зазначене потребує більших зусиль та часу з боку слідчого та процесуального керівника, ніж просто підготувати клопотання до слідчого судді про обрання запобіжного заходу тримання під вартою, це $\epsilon$ другою причиною, яка спонукає до необґрунтованого обрання найбільш тяжкого запобіжного заходу.

Не треба забувати, що йдеться про долю підлітка. Вже ніхто не має сумнівів щодо того, що перебування в умовах установи позбавлення волі має для підлітка більш негативний характер, чим виховний.

Натомість такі запобіжні заходи, як затримання неповнолітнього та його тримання під вартою, варто застосовувати лише в разі, якщо його підозрюють у вчиненні тяжкого чи особливо тяжкого злочину, за умов, що застосування іншого запобіжного заходу не гарантує запобігання ризикам, зазначеним у ст. 177 КПК України.

Ще однією із причин обрання необґрунтованих запобіжних заходів щодо неповнолітніх у вигляді тримання під вартою $€$ грубе порушення норм чинного кримінального процесуального законодавства з боку представників правоохоронних органів, і зокрема неналежна підготовка клопотань до суду, наприклад, недотримання вимог ч. 2 ст. 492 КПК України.

«Так, у справі № 295/9863/16-к слідчим суддею Богунського районного суду Житомирської області 26.07.2016 обрано запобіжний захід у вигляді тримання під вартою щодо неповнолітнього С.А.О., який підозрювався у скоєнні злочинів середньої тяжкості; апеляційним судом рішення скасовано, неповнолітнього звільнено із $\mathrm{Cl} 30$ » [9].

Донині залишається актуальним зазначення ЄСПЛ у справі «Будан проти України»: «Суд уважає, що за обставин цієї справи національні органи влади не обґрунтували належним чином своє рішення про застосування до неповнолітнього заявника запобіжного заходу у вигляді тримання під вартою, яке, відповідно як до міжнародних, так і національних норм, могло бути застосоване лише як конечний захід. Відповідно було порушення п. 1 ст. 5 Конвенції» [10].

Як бачимо, саме невстановлення соціальної характеристики неповнолітньої особи, кола осіб, котрі ії ото- 
чують, не визначення всіх обставин, які мають довести, що саме обраний слідчим запобіжний захід може забезпечити виконання підозрюваним процесуальних обов'язків, а також запобігти ризикам, визначеним у ст. 177 КПК України, призводить до необґрунтованого прийняття рішення про обрання запобіжного заходу у вигляді тримання під вартою та в надмірній кількості.

У разі обрання запобіжного заходу у вигляді тримання під вартою слідчий під час проведення подальшого досудового розслідування повинен звернути увагу на досягнення мети вжитим заходом, наявності виховного впливу й на те, чи $є$ можливість його заміни менш тяжким.

Неповнолітня особа, перебуваючи в умовах ізоляції, поза звичним колом спілкування, може переосмислити свою поведінку, ставлення до вчиненого ним кримінального правопорушення та ставлення до близького оточення, таким чином, необхідність у подальшому застосуванні такого винятково запобіжного заходу, як тримання під вартою, відпадає.

У такому разі, на наш погляд, $\epsilon$ доцільним установлення максимального строку дії ухвали слідчого про обрання запобіжного заходу під час досудового розслідування у вигляді тримання під вартою щодо неповнолітнього - тридцять днів.

Запропонована зміна повністю відповідає принципу відновного правосуддя, яке запроваджується в Україні до неповнолітніх: надання можливості неповнолітній особі усвідомити наслідки своїх вчинків та своє можливе майбутнє.

Необхідність продовження строку запобіжного заходу дозволить слідчому, прокурору та слідчому судді вирішити питання щодо досягнення мети вже застосованого запобіжного заходу, відповідно до положень ст. 177 КПК України, та можливість його зміни на інший, не пов'язаний із позбавленням волі.

Необхідно звернути увагу, що слідчий позбавлений права подавати клопотання про обрання запобіжного заходу у вигляді передачі під нагляд.

Згідно із ч. 6 ст. 493 КПК України «Питання передання неповнолітнього підозрюваного чи обвинуваченого під нагляд батьків, опікунів, піклувальників або адміністрації дитячої установи розглядається за клопотанням прокурора за правилами обрання запобіжного заходу або за клопотанням сторони захисту під час розгляду питання про обрання запобіжного заходу» [5].

Як уже зазначалось, на наш погляд, передання під нагляд - це обмеження процесуальної незалежності слідчого й потребує корегування.

Висновки. 3 метою забезпечення більш виваженого визначення запобіжних заходів щодо неповнолітнього підозрюваного, зменшення питомої ваги клопотань прокурора про обрання запобіжного заходу у вигляді тримання під варту необхідно зробити таке:

1. Унести зміни до ст. 176 КПК України, доповнивши ч. 1 п. 6 «передача під нагляд (тільки щодо неповнолітніх)». (На нашу думку, визначати статус неповнолітнього - підозрюваний чи обвинувачений - потреби немає).

2. Ч. 1 ст. 197 КПК України викласти в такій редакції: «Строк дії ухвали слідчого судді, суду про тримання під вартою або продовження строку тримання під вартою не може перевищувати шістдесяти днів, щодо неповнолітньої особи - тридцяти днів".

3. Ч. 6 ст. 493 викласти в такій редакції «Питання передання неповнолітнього підозрюваного чи обвинуваченого під нагляд батьків, опікунів, піклувальників або адміністрації дитячої установи розглядається за клопотанням слідчого, прокурора за правилами обрання запобіжного заходу, або за клопотанням сторони захисту під час розгляду питання про обрання запобіжного заходу».

\section{Література}

1. Мінімальні стандартні правила Організації Об'єднаних Націй, що стосуються відправлення правосуддя щодо неповнолітніх («Пекінські правила»). [Електронний ресурс]: станом на 10.04.2020. Режим доступу: https:// zakon.rada.gov.ua/laws/show/995_211.

2. Конвенція про права дитини. [Електронний peсурс]: станом на 10.04.2020. Режим доступу: https:// zakon.rada.gov.ua/laws/show/995_021.

3. Конституція України від 28.06.96 р. (із змінами та доповненнями). Відомості Верховної Ради України від 23.07.96 p. № 30. Ст. 141.

4. Запобіжні заходи. Вікіпедія. [Електронний ресурс]: станом на 10.04.2020. Режим доступу: https:// uk. wikipedia.org/wiki/\%D0\%97\%D0\%B0\%D0\%BF\%D0\%BE\%D0\%B 1\%D1\%96\%D0\%B6\%D0\%BD\%D1\%96_\%D0\%B7\%D0\%B0\%D1\%85\%D0\% $\mathrm{BE} \% \mathrm{D0} \% \mathrm{~B} 4 \% \mathrm{D0} \% \mathrm{~B} 8$.

5. Кримінальний процесуальний кодекс України : Закон України від 13.04.2012 р. № 4651-У1 : станом на 10.04.2020 р. [Електронний ресурс]: https://zakon.rada. gov.ua/laws/show/4651-17/print.

6. Сівак О.В. Запобіжні заходи у кримінальному провадженні щодо неповнолітніх : дис. ... канд. юрид. наук : 12.00.09. Національна академія внутрішніх справ. Київ, 2016. 255 c.

7. Статистична інформація про стан злочинності та результати прокурорсько-слідчої діяльності. [Електронний pecypc]: https://old.gp.gov.ua/ua/stst2011.html?dir_id $=113898 \&$ libid $=100820$.

8. Губська О.А. До проблеми дотримання прав неповнолітніх під час обрання щодо них запобіжних заходів. [Електронний ресурс]: https://6aas.gov.ua/ua/ proekty/articles/g/227-do-problemi-dotrimannya-pravnepovnolitnikh-pri-obranni-shchodo-nikh-zapobizhnikhzakhodiv.html.

9. Інформаційний лист ВССУ «Про практику обрання неповнолітнім запобіжного заходу у вигляді тримання під вартою та забезпечення першочергового судового розгляду кримінальних проваджень щодо цієї категорії осіб» № 223-1346/0/4-17 [Електронний ресурс]: https:// zib.com.ua/ua/129705-obrannya_zapobizhnogo_zahodu_ nepovnolitnim_rozyasniv_vss_do.html, назва з екрану.

10. Рішення ЄСПЛ у справі «Будан проти України» (заява № 38800/12) від 14 січня 2016 року. [Електронний ресурс]: https://zakon.rada.gov.ua/laws/show/974_b06, назва з екрану.

Федоров І. В., старший викладач кафедри кримінального процесу факультету підготовки фахівців для органів досудового розслідування Одеського державного університету внутрішніх справ 